\title{
Research on Development Countermeasures of Prefabricated Building in China Based on SWOT Analysis
}

\author{
Yu-Fang Shi*, Shen Kang, Ping-Ping Song \\ School of Management-Xi'an University of Science and Technology in Xi'an, China \\ *Corresponding author. Tel.:15349228419; email: 39597495@qq.com \\ Manuscript submitted December 2, 2016; accepted February 27, 2017. \\ doi: 10.17706/jsw.12.3.165-172
}

\begin{abstract}
Analyze the strengths, weaknesses, opportunities and threats existing in the internal and external environment of prefabricated building of our country. Construct a SWOT analysis matrix, drives some relevant countermeasures on it, then provide suggestions for prefabricated building development in our country.
\end{abstract}

Key words: Prefabricated building, SWOT, prefabricated components, development strategy.

\section{Introduction}

Prefabricated building is composed by components which can be prefabricated in the factory, are transported to the site for installation and formed by way of post-casting concrete. Comparing with the traditional cast-in-place concrete construction method, prefabricated building has the advantages of high production efficiency, high construction quality, small labor demand, saving resources, reducing environmental pollution and so on. Nowadays, with the development of China's social economy and the disappearance of the demographic dividend, the prefabricated building in China has entered into a period of development .

At present, the country attaches great importance to the protection of resources and environment and the transformation and upgrading of economic structure, realizing the need for a resource-saving and environment-friendly society. The construction industry in China has ushered in an important opportunity for the its development, and has a trend of development. At present, however, there are a lot of problems in the development of the assembly building. And this paper puts forward the strategic orientation of the development of the assembly building based on the SWOT analysis, and provides suggestions for the development of the assembly building in our country.

As early as in the 1950s, China has put forward the development of prefabricated buildings. Till 1980s, our country has been in the start-up phase for the prefabricated building, learning lessons from the foreign advanced experience, and did a lot of studies and practice combined with the situation in our country. But due to the relatively backward technology, the comprehensive benefits of building industrialization is very low. In 90s, China began to implement the housing market and housing construction developed rapidly. Due to the low technology of prefabricated construction and the rapid development of cast-in-place concrete technology, the development and application of prefabricated building stagnated. After 2000, with China's rapid economic development, the labor cost rise, a lot of problems caused by cast-in-place construction began to exposed like resources waste and environmental pollution, and people's awareness of 
environmental protection improved, which brought the active development of prefabricated buildings again.

\section{The Main Advantages and Disadvantages, Opportunities and Threats Analysis of Assembly Construction}

\subsection{Main Advantages}

\subsubsection{High production efficiency}

Prefabricated building is composed by prefabricated parts on site, which are produced in the factory. Prefabricated part standardization makes it produced mechanically to ensure the production speed and the supply continuity. Component on site should be only need to cast the node which greatly reduce the construction difficulty and workload. The surface of prefabricated wall panel assembling building is needn't to be level, shortened the construction time. At the same time, prefabricated building is not affected by seasonal and weather constraints and it can be constructed in rain and snow weather, which both ensure the schedule of construction and reduce the construction cost [1].

\subsubsection{High quality construction}

Due to the centralized prefabrication and unified production, the concrete mix ratio, sand and stone washing, sand and stone matching ratio, the number of steel and other factors to be controlled more precisely. The construction technology process of single component is easier than the traditional cast construction technology, which is conducive to quality control, so the prefabricated building can be improved in the quality of the whole project through the individual components [2]. In addition, the traditional building construction room size and the hole size of doors and windows often have errors and other issues. In the prefabricated building construction, not only the error of the room, windows and doors size can be reduced, but also the windows installation technology can be more accurate than the traditional process, which can prevent the leakage of windows.

\subsubsection{Save resources, reduce consumption}

Prefabricated building construction uses standardized, serial and generalized prefabricated concrete components, which saves a large number of templates. The prefabricate produced by precast factory, reduces the construction site wet work, avoiding the spilling and dripping phenomenon of the traditional building construction site and saving a lot of water and mortar, but also protecting the cleanliness of the construction site. Prefabricated building uses prefabricated wall and composite floor, which greatly reduces the use of scaffolding and formwork supporting, which saves the amount of wood reached $40 \%$, not only reducing the construction cost, but also protecting the forest resources [3].

\subsubsection{Cleaner Production}

Prefabricated building can reduce the transportation, stacking and loading and unloading of building materials, which can effectively reduce the impact of dust on the surrounding environment. Prefabricated building makes most of the site construction into plant processing, so that it can effectively reduce the solid waste and sewage discharge, reduce dust and noise pollution, and is conducive to environmental protection. In addition, prefabricated building also reduces the concrete pump in the transportation and operation noise, and noise in the installation and removal of template, greatly reducing the construction disturbing phenomenon.

\subsection{Main Disadvantages}

\subsubsection{Industrial policy support is not enough}

Before the day, the CPC Central Committee and the State Council several opinions on Further 
Strengthening the City Panning and Construction Management Work, put forward to strive to use 10 years, to achieve the target that prefabricated building accounting for $30 \%$ of the total new building. Although China has introduced some related policies and regulations of prefabricated building, and made some progress, but is lack of some national level, targeted regulatory policies. For the development of prefabricated building in detail, the system of policy research and development still has a lot of blank, with the whole industry chain as the foundation of the policy, laws and regulations still need to further improve and perfect. Prefabricated building as energy saving and environmental protection projects, the prefabricated is levied 17\% VAT, which does not enjoy the corresponding preferential policies.

\subsubsection{The standard system is not perfect enough}

In June 2015, the introduction of the Ministry of Housing and Urban Construction authorized Chinese Building Standard Design Institute to complete the first construction industry modernization in China national building standard design system, which provides strong technical support for China's construction industry development; and Industrial Building Evaluation Criteria which was responsible by the Ministry of Housing and Urban has been formally implemented in January 2016 has an important role in guiding and regulating. But current national and local have not yet introduced specific component production, construction and quality inspection standards and procedures, lack of supporting the implementation details, traditional regulatory measures do not adapt to the new mode of production for the precast production enterprise access threshold is relatively low. Especially those products and services, a lot of products and services are in the blank area of product quality standards [4].

\subsubsection{The high cost of construction}

At present, Prefabricated building production enterprises are in the grope market stage, prefabricated production is low, it has not formed the production scale, so the cost is high comparing with the traditional cast-in-situ concrete structure. According to statistics, the cost per square meter is higher the 700-800 Yuan than cast-in-place style buildings. The cause of the higher cost of prefabricated building components lies in the transportation and hoisting installation cost is high. Due to the one-time investment of the prefabricated factory is large, the current market demand is small, production is not high cause high cost amortization component. Business tax in accordance with the prefabricated industrial enterprises, prefabricated VAT reached $17 \%$, increased production costs, is not conducive to the promotion of assembly building [5].

\subsubsection{Shortage of professional talents}

Now our country's management system and personnel training mechanism of construction industry can not adapt to its need, the colleges and universities have no "prefabricated" professional basically, nor on the technical training of workers on social channels, the talent flow is also great, many companies are pursuit of "skilled" in the process of hiring, and neglect the cultivation of their own talent; the high technical barriers within the industry hinders technological exchanges and progress etc..Installation of prefabricated building requires for high transport and hoisting equipment, while the ordinary construction team, workers are of low quality, lack of experience and difficult to construct.

\subsection{Major Opportunities}

\subsubsection{National policy support}

Government should be policy-oriented, and promotes the development of the a prefabricated building, promote the transformation and upgrading of construction enterprises. "Thirteen Five" plan proposed the development of new construction, and actively promote the development of prefabricated building, shorten the construction period, improve project quality, and reduce construction waste emissions and reduce dust pollution; improve the prefabricated building from design to acceptance specifications and other aspects; 
accelerate the standardization of components, building components to achieve industrial production, construction of national assembly building production base; increase policy support efforts to expand the proportion of prefabricated buildings in new construction, so that the assembly building has a larger market share in the construction market [6].

\subsubsection{Less labor demand}

Over the past three decades, China's construction industry experienced rapid development, one of the main reasons is the low labor costs. With the change of the relationship between labor supply and demand, rising labor costs, labor shortage problems exposed gradually, which become an important factor restricting the development of China's construction industry. Construction transformation is an inevitable trend, rising labor costs has become an important factor in promoting the construction of industrial structure adjustment, promote industrial restructuring and building objectively, improve production technology, promote production mechanization, and accelerate the pace of development of the assembly building.

\subsubsection{Joint research closer}

Promoting the building industrialization and developing assembly building is inseparable from the close cooperation in research. Five domestic civil construction leading universities Southeast University, led by the United Tsinghua University, Tongji University, Zhejiang University, Hunan University, and China State Construction Engineering Corporation and other industry leaders and fifteen research institutions jointly organized the "industrialization of new building collaborative innovation Center "will develop the prefabricated building the necessary conditions required for effective and innovative elements together to set up innovation platforms and to provide bases for the prefabricated building technology research and development, test, deployment, diffusion and various talents.

\subsection{Main Threat}

\subsubsection{Recognize errors}

Comparing with traditional construction methods, the prefabricated building is a new building construction methods; building industry, prefabricated housing and other concepts yet deep into everyday life among ordinary residents. Most people are in a very general state with the concept of prefabricated buildings, do not know the new technologies and new materials employed experience the advantage of prefabricated buildings by themselves. Thus, ordinary residents' skepticism of the assembly building is not conducive to the implementation and development of prefabricated buildings.

\subsubsection{The lack of supporting industrial chain}

Building industrialization needs integration from design, production, construction, operation to maintenance, which involves companies, such as owners, design units, components factories, construction units, from all of the upstream and downstream enterprises to form a complete industrial chain. less experience of design units, less prefabricated enterprises, some of the production lines are not open enough, resource supply chain is not rich, these factors all lead to the construction costs increasing, limiting the development of prefabricated buildings [7].

\subsubsection{Backward management system}

Currently information management of prefabricated buildings still remain in the traditional management mode; field operators have to manually record the current state of production, to complete the statistical summary of the information by hand, which is clearly in low efficiency. With the further development of prefabricated buildings, in order to improve management efficiency and reduce costs, we should establish a prefabricated building system to improve project management efficiency, information exchange sharing and 
to ensure accurate, timely transmission of information , and the pass track is clear.

\section{Put Forward the Development Strategy of Assembly Building Based on SWOT Matrix}

\subsection{Constructing SWOT Matrix of Prefabricated Building}

Based on the above analysis, establishes SWOT matrix, as shown in Table 1.

Table 1. SWOT Matrix of Prefabricated Building

\begin{tabular}{|c|c|c|}
\hline & $\begin{array}{l}\text { Advantages } \\
\text { 1. High production efficiency. } \\
\text { 2. High construction quality, good } \\
\text { performance. } \\
\text { 3. Save resources, reduce } \\
\text { consumption. } \\
\text { 4. Cleaner production. } \\
\text { 5. Less noise pollution. } \\
\text { 6. Can learn from the advanced } \\
\text { experience of foreign countries. } \\
\text { 7. Broad market prospects. }\end{array}$ & $\begin{array}{l}\text { Disadvantages } \\
\text { 1. Industrial policy support is not } \\
\text { enough. } \\
\text { 2. Standard system is not perfect } \\
\text { enough. } \\
\text { 3. High cost of construction. } \\
\text { 4. Lack of professional talents. } \\
\text { 5. High specialization, and the } \\
\text { construction is difficult. } \\
\text { 6. Can't meet the individual needs. } \\
\text { 7. The component is not } \\
\text { conducive to the transportation. }\end{array}$ \\
\hline $\begin{array}{l}\text { Opportunities } \\
\text { 1. National policy support. } \\
\text { 2. Less artificial demand. } \\
\text { 3. The combination of production } \\
\text { and research is more closely. } \\
\text { 4. The transformation of economy } \\
\text { and industrial structure to } \\
\text { provide opportunities for the } \\
\text { development of assembly } \\
\text { building. } \\
\text { 5. The economic development of } \\
\text { the country is in good condition. } \\
\text { 6. Global economic integration } \\
\text { provides more resources and } \\
\text { greater market. } \\
\text { 7. Construction industry in } \\
\text { China's economic structure is still } \\
\text { the main building. }\end{array}$ & $\begin{array}{l}\text { SO strategies } \\
\text { 1. using policy support to expand } \\
\text { production and reduce } \\
\text { construction cost. } \\
\text { 2. Increase R \& D investment and } \\
\text { learn from foreign advanced } \\
\text { technology, according to the } \\
\text { national conditions, establish } \\
\text { scientific technical system. } \\
\text { 3. Make use of opportunities to } \\
\text { expand the market share. }\end{array}$ & $\begin{array}{l}\text { WO strategies } \\
\text { 1. Strengthen the support and } \\
\text { protection of the policy and law. } \\
\text { 2. Play the role of government } \\
\text { guidance, investment in the } \\
\text { construction of affordable } \\
\text { housing. } \\
\text { 3.Cultivate professional talents, } \\
\text { set up technical team, reduce the } \\
\text { difficulty of construction. }\end{array}$ \\
\hline $\begin{array}{l}\text { Threats } \\
\text { 1. Consumer's thinking behind } \\
\text { and misunderstanding. } \\
\text { 2. Lack of supporting industry } \\
\text { chain. } \\
\text { 3. Backward management system. } \\
\text { 4. Small market share. } \\
\text { 5. Regional development is not } \\
\text { balanced. } \\
6 \text {. Has not formed a stable } \\
\text { professional construction team, } \\
\text { staff mobility. } \\
\text { 7. Excessive administrative } \\
\text { means. }\end{array}$ & $\begin{array}{l}\text { ST strategies } \\
\text { 1. Perfect related industry chain, } \\
\text { rich resources of supply chain. } \\
\text { 2. Improve the management level, } \\
\text { save time, improve production } \\
\text { efficiency. } \\
\text { 3. Establish a talent incentive and } \\
\text { restraint mechanism to retain } \\
\text { talent. }\end{array}$ & $\begin{array}{l}\text { WT strategies } \\
\text { 1. Establish technical standard } \\
\text { system, realize standardization } \\
\text { and scale. } \\
\text { 2. Strengthen publicity, improve } \\
\text { the recognition, and actively } \\
\text { promote the development of } \\
\text { prefabricated building } \\
\text { 3. Promote the application of BIM } \\
\text { technology in the prefabricated } \\
\text { building. }\end{array}$ \\
\hline
\end{tabular}

\subsection{The Development Strategy of Prefabricated Building}

According to table 1 of the SWOT matrix of to produce a variety of prefabricated building strategies 
appears as follows

\subsubsection{Reduce building cost}

At present, the high cost of prefabricated building in our country is not conducive to its development, but the construction of affordable housing provides opportunities for the development of the prefabricated building and expanding the production capacity of prefabricated component and reducing the cost of construction. Prefabricated component is levied 17\% VAT as commodity, it is not conducive to the popularization of prefabricated building. It is appropriate to reduce the prefabricated component VAT so as to reduce the cost of the component, optimize design of component, and improve production process, increasing the utilization rate of the component and the mold turnover to reduce the cost of the component [8].

\subsubsection{Strengthen the support and protection of the policy and law}

The development of prefabricated buildings in our country cannot do without support of relevant national policies, which is an important measure to promote the development of the prefabricated building. The prefabricated building in our country is in the initial stage, so the scale effect can't be reflected, requiring the government to introduce relevant supporting policies, encourage rational construction scale to achieve the expected benefits. With the rapid development of prefabricated construction, relevant policies and regulations are needed, laws and regulations are needed to established to supervise and implement and to ensure the healthy and rapid development of prefabricated building, reflecting the advantages of prefabricated building.

\subsubsection{Perfect related industry chain}

To integrate the owners, design units, component factory, construction units, and all the upstream and downstream enterprises into a complete industrial chain, realize the prefabricated building integration from the design, production, construction, post operation and maintenance so that all enterprises in the industrial chain can cooperate better, and continuously integrate the advantages of each enterprise in the process of project construction to improve the efficiency of prefabricated building and promote the development of the prefabricated building [9].

\subsubsection{Establish technical standard system}

At present, the standardization and generalization of the prefabricated building components in our country is low, so it is better to first establish a standard system of architectural design to reasonable plan and control the diversity of prefabricated components, so that the popularity and interchangeability of component become a reality, and make provisions for different component standardization, modular [10], quicken the speed of design and construction efficiency.

\subsubsection{Strengthen the training of professional talents}

Construction of prefabricated building is difficult [11], especially in transportation and hoisting, which has a higher technical requirements for the practitioners. It is needed for specialized personnel and to form a technical team. Enterprises can train the potential construction workers to carry out special skills training, improve the quality and skills of construction personnel. In order to prevent the brain drain, enterprises should also make the welfare system of the technical staff. it is needed to increase production and research cooperation [12], pay attention to personnel training, proposed to set up related majors in Colleges and universities and pay attention to the training mode combining theory and practice.

\subsubsection{Promote the BIM information technologies}

In the trend of building information, BIM, as a new information technology, is a kind of information 
management system, which is used in the design, production, construction and so on, It can build an information exchange platform for all the participating parties to ensure accurate data transmission. Management efficiency is greatly improved through making use of BIM software to make the virtual building for construction simulation, data statistics, engineering calculation, etc. [13], [14].

\section{Conclusion}

With the transformation of China's economy and industrial structure, prefabricated building is the inevitable trend of the future development of the construction industry. Facing with the opportunities and challenges, combined with the advantages and disadvantages of the prefabricated building, we should make the strategy for the development of the prefabricated building, such as increasing policy support, perfecting the technical standard system, increasing R \& D investment, training professional personnel, improving the industrial chain, etc., to promote the healthy and rapid development of prefabricated building and to promote the building industrialization and sustainable development.

\section{Reference}

[1] Dai, C. C., Xu, X., \& Zhang, L. (2015). SWOT analysis of prefabricated concrete building development in China. Construction Economics, 36(2), 10-13.

[2] QI, B. K., \& Zhang, Y. (2015). Prefabricated construction development bottleneck and countermeasures research. Journal of Shenyang Jianzhu University(Social Science), 17(2), 156-159.

[3] Yang, X. C., Qian, Q. F., \& Tang, Z. H. (2015). Preliminary study on the characteristics and adaptability of prefabricated construction in background of domestic architectural industrialization. Value Engineering, 34, 78-82.

[4] Li, C. K. (2014). The key issues constraining the development of China's construction of industrialization and countermeasures research. Liaocheng University.

[5] Wu, S. G., Guo, R., \& Liu, Y. (2013). Association analysis of building industrialization and labor cost. Building Construction, 35(2), 172-175.

[6] LI, J. H. (2012). Study on the Restricting Factors of Development of Housing Industrialization and Countermeasures of China . Chongqing University.

[7] Chen, Z. J. (2015). Reasons and countermeasures for slow development of china housing industrialization. Architecture Technology, 3, 235-238.

[8] LI, L. H., Xiao, Z. H., \& Fu, X. (2014). Analysis on construction cost of prefabricated building. Construction Economics, 11, 63-67.

[9] Norman, M., Terrence, F., \& Ghassan, A. (2003). A virtual environment for the design and simulated construction of prefabricated buildings. Virtual Reality, 64 .

[10] Toole, T. M., \& Gambatese, J. (2008). The trajectories of Prevention through Design in construction. Journal of Safety Research.

[11] Duan, K. Y., \& Zhang, J. C. (2014). Research on integration of design and construction of precast concrete residence. Construction Technology, 22, 45-47.

[12] Bryde, D. M., \& Broquetas, V. J. M. (2013). The project benefits of building information modelling. International Journal of Project Management, 31(7), 971-980.

[13] Banihashemi, N. S., Moharrami, M. M., \& Karimi, V. Y. (2012). Developing IFC standards for implementing industrialized building system components into BIM applications. Proceedings of the Economics Development and Research.

[14] Ghafar, M. A., Ibrahim, R., \& Shari, Z. (2014). Embedding cultural knowledge in building information modeling (BIM) for fabrication efficiency to reduce industrialized construction. Computing in Civil and Building Engineering. 


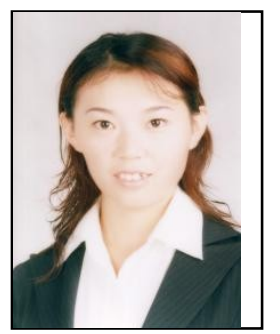

Yu-Fang Shi is an associate professor in School of Management-Xi'an University of Science and Technology in Xi'an, China. Her research interest covers Management of Engineering Project and Appraisal of Investment Project.

She received numerous scholastic awards, including the second prize of the first session of the national coal higher education excellent teaching material awarded by China's coal education association in 2010,the second prize of 2011 excellent teaching material of Xi'an university of science and technology awarded by Xi'an university of science and technology. Her publications included Introduction of Project Management[M](Xi'an,Xi'an Electronic and Science University press,2013), Research on construction reliability calculation method of engineering project $[\mathrm{C}](2014$ the second International Conference on Frontiers of Advanced Materials and Engineering Technology).

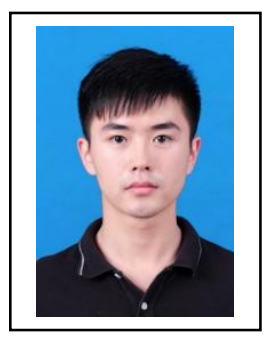

Shen Kang is a graduate student of School of Management-Xi'an University of Science and Technology in Xi'an, China. His major is civil engineering. His research interest is management of engineering project.

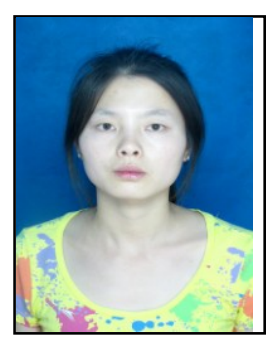

Ping-Ping Song is a graduate student of School of Management-Xi'an University of Science and Technology in Xi'an, China. Her major is technical economy and management. Her research interest is appraisal of investment project. 